SISTEMA
ELETRÔNICO
DE REVISTAS
SER I UFPR

\title{
Os efeitos do Programa Cisternas no acesso à água no semiárido
}

\section{The effects of the Cisterns Program on water access in the semiarid region}

\author{
Igor da Costa ARSKY ${ }^{1^{*}}$ \\ ${ }^{1}$ Ministério da Economia, Brasília, DF, Brasil. \\ ${ }^{*}$ E-mail de contato: igor.arsky@gmail.com
}

Artigo recebido em 25 de abril de 2020, versão final aceita em 20 de setembro de 2020, publicado em 18 de dezembro de 2020.

RESUMO: Este artigo destaca a reconfiguração do acesso à água pela população rural difusa de baixa renda do semiárido a partir do Programa Cisternas, segundo a percepção de seus implementadores. Ainda marcado pela concentração fundiária, o semiárido brasileiro abriga uma numerosa população de moradores rurais e pequenos produtores em minifúndios com problemas de quantidade, qualidade e regularidade no acesso à água. Essas famílias precisam se utilizar de variadas fontes de água externas ao domicílio para o suprimento de suas necessidades e estão ainda sujeitas ao seu uso político. No entanto, revertendo uma trajetória histórica ineficaz de intervenção pública, uma parceria bem-sucedida entre Estado e sociedade civil pôs em marcha um abrangente programa de formação e construção de cisternas e outras tecnologias sociais, que melhoram o acesso à água de cerca de 1,3 milhão de famílias. Assim, o artigo explora o resultado de 31 entrevistas realizadas em Brasília, Bahia, Alagoas e Pernambuco, entre setembro de 2018 e abril de 2019, com implementadores do Programa em diversos níveis, que responderam à seguinte questão: o Programa Cisternas mudou o acesso à água no semiárido?

Palavras-chave: acesso à água; semiárido; cisternas.

ABSTRACT: This article highlights the reconfiguration of water access in the diffuse low-income rural population of the semiarid region, according to the perception of the people implementing the Cisterns Program. Still marked by land concentration, the Brazilian Semiarid is home to a large population of rural residents and small producers in smallholdings with problems of quantity, quality and regularity in access to water. These families need to use various sources of water outside their homes to supply their needs and are still subject to their political use. However, reversing an ineffective historical trajectory of public intervention, a successful partnership between 
the State and civil society set in motion a comprehensive program for the formation and construction of cisterns and other social technologies, which improve water access by around 1.3 millions of families. Thus, this article explores the result of 31 interviews conducted in Brasília, Bahia, Alagoas and Pernambuco, from September 2018 to April 2019, with implementers of the Program at various levels, who answered the following question: did the Cistern Program change the water access situation in the semiarid?

Keywords: access to water; semiarid; cisterns.

\section{Introdução}

A região do semiárido possui uma cultura marcante, que é retratada em romances, livros, músicas, poesias, cinema, merecendo destaque as dimensões culturais e religiosas ligadas às festas populares, aos hábitos alimentares, à musicalidade e a um catolicismo popular, historicamente arraigado. No entanto, o semiárido também é marcado no imaginário social pelas consequências das secas periódicas que ocorrem na região. Contando com a presença numerosa de minifúndios, moradores rurais e pequenos agricultores familiares, a região avança no século XXI com uma das maiores proporções de famílias de baixa renda e um dos menores índices de desenvolvimento humano do país. A cobertura de domicílios ligados à rede pública de abastecimento de água, principalmente para a população rural difusa de baixa renda, segue sendo baixa, mas um abrangente programa de construção de cisternas reconfigurou as condições de acesso à água para essa população.
Trata-se do Programa Nacional de Apoio à Captação de Água de Chuva e Outras Tecnologias Sociais de Acesso à Água - Programa Cisternas, instituído pela Lei n. 12.873, de 24 de outubro de $2013^{1}$ (arts. 11 a 16), que tem por finalidade promover o acesso à água para o consumo humano e animal e para a produção de alimentos, por meio da implementação de tecnologias sociais junto à população rural de baixa renda. O Programa Cisternas é coordenado pela Secretaria Nacional de Inclusão Social e Produtiva Rural ${ }^{2}$ da Secretaria Especial de Desenvolvimento Social do Ministério da Cidadania ${ }^{3}$, que abriga a Coordenação Geral de Acesso à Água, responsável pela gestão nacional do programa.

Destacar a institucionalização do Programa Cisternas e caracterizar seus efeitos na reconfiguração do acesso à água no semiárido são os objetivos deste artigo, que se apoia no resultado de pesquisa da dissertação de mestrado Determinantes, efeitos e a institucionalização do Programa Cisternas na visão dos implementadores (Arsky, 2019). A referida pesquisa teve como objetivo analisar os

\footnotetext{
${ }^{1}$ Que resultou da conversão da Medida Provisória n. 619, de 6 de junho de 2013, e que foi regulamentada pelo Decreto n. 8.038, de 4 de julho de 2013, e demais portarias e instruções normativas, constituindo-se o que os operadores da política chamam de Marco Legal do Programa Cisternas.

${ }^{2}$ Secretaria Nacional de Segurança Alimentar e Nutricional (SESAN), entre 2004 e 2018.

${ }^{3}$ O Ministério da Cidadania foi antecedido pelo Ministério do Desenvolvimento Social e Agrário (MDSA) entre 30 de setembro de 2016 e 31 de dezembro de 2018 e, antes disso, pelo Ministério do Desenvolvimento Social e Combate à Fome (MDS), entre janeiro de 2004 e setembro de 2016.
} 
determinantes, os efeitos e a institucionalização do Programa na visão de atores que estiveram implicados na sua implementação ${ }^{4}$. Para isso, a pesquisa envolveu entrevistas tanto com o Poder Público como com as organizações da sociedade civil participantes do Programa. No âmbito da sociedade civil, foram realizadas entrevistas com dirigentes da Associação Programa Um Milhão de Cisternas (AP1MC), bem como com lideranças e técnicos de três organizações pertencentes à rede Articulação Semiárido Brasileiro (ASA), a saber: Movimento de Organização Comunitária (MOC), com sede em Feira de Santana (BA), Associação Regional de Convivência Apropriada ao Semiárido (ARCAS), com sede em Cícero Dantas (BA), e Caritas Diocesana de Pesqueira, com sede em Pesqueira (PE).

No âmbito do Poder Público, a pesquisa envolveu entrevistas nas três esferas de Governo. Além da Gestão Nacional do Programa Cisternas, foram entrevistados dirigentes e técnicos do governo dos estados de Pernambuco e da Bahia, bem como dos Consórcios Intermunicipais de Desenvolvimento da Região do Ipanema (AL) e de Desenvolvimento Sustentável do Território Bacia do Jacuípe (BA). A pesquisa envolveu ainda beneficiários e lideranças da sociedade civil local envolvidas na implementação do Programa em comunidades de três municípios (Buíque-PE, Fátima-BA e Feira de Santana-BA). Ao todo, foram realizadas trinta e uma entrevistas.

As entrevistas se apoiaram em questionários semiestruturados específicos para cada ator entre- vistado, de acordo com a posição e o papel de cada um deles no processo de implementação. Vale assinalar, no entanto, que uma questão foi formulada e explorada com todos os entrevistados, qual seja, se o Programa Cisternas havia mudado o acesso à água no semiárido.

Além desta introdução, o artigo está dividido em cinco partes. A primeira trata do semiárido e do acesso à água da população rural difusa no contexto da intervenção histórica do poder público. A segunda parte trata da apropriação no Estado da proposta política de construção de cisternas e de convivência com o semiárido. As duas partes seguintes apresentam o resultado da pesquisa no que tange aos efeitos do Programa na realidade local tendo em vista o acesso à água para consumo e produção, respectivamente. Por fim, apresentam-se os comentários finais.

\section{O acesso à água da população rural do Semiárido e a Intervenção do Poder Público}

O território legalmente denominado como semiárido foi delimitado pelo governo federal nos termos da Resolução SUDENE ${ }^{\circ} 115$, de 23 de novembro de 2017, abrangendo 1.262 municípios de dez estados brasileiros (Alagoas, Bahia, Ceará, Maranhão, Paraíba, Pernambuco, Piauí, Rio Grande do Norte, Sergipe e Minas Gerais), em uma área de $1.128 .697 \mathrm{~km}^{2}$, abrangendo uma população de 27.870.241 pessoas (Brasil, 2017), ampliando em 127 municípios em relação à delimitação oficial

\footnotetext{
${ }^{4}$ A análise da institucionalização do Programa Cisternas e seus efeitos foi agrupada na dissertação da seguinte forma: efeitos no executivo federal, efeitos nos dos demais entes federados, efeitos na sociedade civil e efeitos na realidade local. Este artigo destaca este último enfoque, qual seja, dos efeitos da institucionalização e da implementação na realidade local.
} 
anterior, estabelecida pela Portaria n. 89, de 16 de março de 2005 (Brasil, 2005a). Segundo os critérios da Portaria n. 89 (vigentes no período de implementação do Programa), esse território abrangeria 1.135 municípios de nove estados brasileiros (Alagoas, Bahia, Ceará, Paraíba, Pernambuco, Piauí, Rio Grande do Norte, Sergipe e Minas Gerais), em uma área de $980.133,079 \mathrm{~km}^{2}$, o que representava cerca de $20,4 \%$ dos municípios e $11,5 \%$ do território brasileiro (INSA, 2012). De acordo com dados do censo demográfico de 2010, mais de 22,5 milhões de pessoas estavam localizadas nesta região, sendo 8,5 milhões na zona rural (Santana et al., 2011; INSA, 2012).

A condição de clima semiárido e a conformação de seu principal ecossistema, o bioma caatinga, são resultado da combinação de elevadas taxas de evapotranspiração, do caráter concentrado das precipitações anuais e do predomínio de solos rasos, característico do embasamento cristalino que abrange $70 \%$ do território, com pouca capacidade de armazenagem de água em aquíferos (Nobre, 2012), que apresenta, em geral, águas salinizadas, com poços que secam com bombeamentos constantes. Essas características geoambientais influenciam a quantidade hídrica explorável no semiárido, uma vez que os níveis de precipitação e escoamento superficial são pequenos, se comparados ao restante do país, e a eficiência hidrológica dos reservatórios é extremamente baixa, em função das altas taxas de evaporação (Suassuna, 2005). Previsões feitas no âmbito do Painel Intergovernamental sobre Mudanças Climáticas (IPCC) acerca do fenômeno mundial das mudanças climáticas apontam para uma elevação da temperatura média na região, o que deve ocasionar a diminuição da pluviosidade média e o aumento da ocorrência de secas, crescendo também o risco do aumento da desertificação (Nobre, 2012).

Há irregularidade espacial das chuvas, que se concentram em quatro meses durante $o$ ano, podendo ocorrer as chamadas secas, período prolongado de estiagem durante o período climatologicamente chuvoso (Nobre, 2012). A ocorrência de secas anuais ou plurianuais é um fenômeno climático característico, intrínseco e, portanto, normal da região semiárida.

A formação econômico-social do semiárido tem origem no povoamento da região a partir do século XVI por criadores de gado, que fez surgir um "outro nordeste", das caatingas e do gado, que abastecia e complementava o nordeste do litoral e do açúcar ${ }^{5}$. No século XIX, o semiárido seria impactado pela expansão e pela diversificação dos mercados internacionais de produtos primários, fazendo surgir, no âmbito das grandes fazendas, uma economia agropecuária de extrema fragilidade, orientada para produzir excedentes de exportação, dando contornos mais nítidos à formação econômico-social da região, marcada pelo binômio latifúndio-minifúndio e pelo tripé pecuária, algodão e subsistência. A ocupação do território e o sistema de sesmarias provocaram a existência dessa dualidade no setor agrícola, entre o latifúndio, reconhecido jurídico e socialmente, e o roçado, com presença permanente, mas sem proteção legal (Andrade, 1988).

\footnotetext{
${ }^{5}$ Ver obra clássica de Djacir Menezes, O outro Nordeste: ensaio sobre a evolução social e política do Nordeste da "civilização do couro" e suas implicações históricas nos problemas gerais, de 1937. A expressão “o outro Nordeste” faz referência à obra clássica de Gilberto Freyre, que analisou o nordeste da Zona Canavieira.
} 
A atividade econômica da região, por sua vez, era sobreposta por três camadas: a criação de gado, que gerava renda para os grandes proprietários; o cultivo agrícola do algodão mocó (e outras xerófilas), que era realizado no sistema de meia, no qual a renda gerada era dividida entre o proprietário das terras e o trabalhador; e, por fim, o cultivo de subsistência de produtos alimentares, que não gerava renda, mas provinha o sustento dessa população que se espraiara e se fixara nas fazendas. Na ocorrência da seca, a principal atividade afetada era a produção de alimentos de subsistência, transformando a seca em calamidade social (Brasil \& GTDN, 1959). Para Furtado (1989, p. 20), “não se vinculando ao mercado como produtor, tampouco como supridor de mão de obra, o trabalhador da grande fazenda surgida no século XIX no semiárido tem um estatuto próximo ao dos camponeses submetidos ao sistema de servidão".

As secas assumem feições de calamidade social a partir da seca de 1877-1879, que despertou populações e políticos para a gravidade do tema (Campos, 2012). A seca torna-se tema central no discurso dos representantes políticos, que passaram a interpretar todas as demais questões a partir da influência do meio e de sua "calamidade" (Albuquerque Jr., 2011, p. 73). Uma nova seca assolaria a região entre 1915-1919 e, na década de 1920, começaria a surgir nos discursos a separação entre a área amazônica e a área "ocidental" do Norte. O Nordeste, que se constituiu, formalmente, nos anos de 1910-1920, “é, em grande medida, filho das secas" (Albuquerque Jr., 2011, p. 68)

A Inspetoria de Obras Contra as Secas (IOCS), criada na Primeira República por pressão dos governadores, logo se veria desacreditada, pois acumulava verbas de socorro às vítimas em mãos de políticos influentes, comerciantes e proprietários conhecidos como os "industriais das secas" (Andrade, 1988). Nesse período, ganhariam grande repercussão as secas de 1932, 1952 e 1958 (Carvalho, 2012). Essa última gerou uma reação do governo de Juscelino Kubitschek, visando levar à modernização ao nordeste. Os propósitos transformadores que viabilizaram a criação da Superintendência de Desenvolvimento do Nordeste (SUDENE), em 1959, foram abandonados progressivamente com o advento do regime miliar. Restou à SUDENE uma atuação quase que circunscrita ao fomento industrial, "que não ameaçava a estabilidade político-social dos grupos tradicionais de poder econômico local e evitava o 'choque frontal' com as oligarquias agrárias" (Bursztyn, 2008, p. 46).

As políticas de desenvolvimento agrícola a partir dos anos 1970, como a expansão do crédito rural, o estímulo ao cooperativismo, a assistência técnica e extensão rural e os projetos de irrigação, pouco alcançaram a população rural difusa (Bursztyn, 2008). Entre 75\% e 90\% do volume de crédito foram direcionados aos grandes proprietários (acima de 100 ha), acentuando a tendência à "bovinização" do semiárido (Bursztyn, 2008, p. 67). Na política de irrigação, o papel do Estado foi, por um lado, de patrocinador (sponsor) do grande capital na exploração do vale do São Francisco e, por outro lado, adotou uma postura paternalista e autoritária para transformar as unidades familiares camponesas em produtores capitalistas, junto aos "colonos" ou "irrigantes" dos perímetros irrigados. Como efeito direto dessas políticas tem-se a estratificação da sociedade local segundo o grau de participação nos benefícios trazidos pela ajuda oficial (Bursztyn, 2008). 
O fracasso das políticas do regime militar se fez salientar por ocasião da grande seca de 1979-84, quando as estruturas existentes não foram capazes de oferecer melhor assistência aos flagelados, utilizando-se os mesmos métodos das secas anteriores (Andrade, 1988). Na seca de 1993, foram alistados 2,1 milhões de pessoas nas frentes de emergência e, na seca de 1998-1999, foram distribuídas três milhões de cestas básicas (Silva, 2006). Os investimentos em irrigação - assim como o início dos projetos de desenvolvimento rural em cooperação com o Banco Mundial, que incorpora as ideias de desenvolvimento rural integrado e a de polos de desenvolvimento - beneficiaram elites políticas e econômicas, reforçaram desigualdades estruturais e mantiveram a concentração da distribuição de água. Os governos pós-ditadura continuaram reproduzindo velhas práticas de combate à seca, privilegiando elites políticas e econômicas e os programas destinados à melhoria da distribuição de água para as populações rurais caracterizaram-se pela fragmentação, desarticulação e descontinuidade das ações. Os programas não chegavam a todos os lugares, nem objetivavam a universalização do acesso à água (Pereira, 2016).

O censo agropecuário de 2006 viria a confirmar a elevada concentração da propriedade de terra no semiárido. Dos 1,7 milhão de estabelecimentos agropecuários do semiárido, cerca de 1,1 milhão são minifúndios, tendo menos de 5 hectares (Buainain \& Garcia, 2013). Situação que se reflete também no acesso à água, uma vez que "a má distribuição das águas no Semiárido está umbilicalmente associada à grande concentração fundiária. Trata-se de uma histórica estrutura concentradora de terra, água, riquezas e poder" (IPEA, 2013).
Levantamento realizado com base no censo demográfico de 2010 por Santana et al. (2011) indicava que dos cerca de 1,7 milhão de domicílios da zona rural do semiárido, apenas 33,9\% estavam ligados à rede pública de abastecimento, 42,6\% eram abastecidos por poço ou nascente, $5,7 \%$ por carro-pipa e $17,7 \%$ por cisternas. A baixa cobertura de domicílios ligados à rede pública de abastecimento de água evidencia a situação generalizada na zona rural do semiárido de insegurança hídrica, principalmente para a população rural difusa.

Para Souza Filho (2012), há no semiárido uma clivagem estabelecida por aqueles que pertencem e os que não pertencem a um sistema de recursos hídricos (hidrossistema). Os que não pertencem a um sistema de recursos hídricos, salienta, são frequentemente as populações rurais difusas e a agricultura de sequeiro (Souza Filho, 2012, p. 200-201).

A população rural difusa representa a população que está espalhada nos minifúndios e pequenas propriedades por toda a zona rural do semiárido, entremeados por grandes fazendas, cidades, vilas e distritos. Às vezes, os minifúndios estão dispersos, isolados, mas na maioria dos casos se aglomeram, formando comunidades rurais. A natureza de ocupação dispersa no semiárido, por si só, impede a viabilidade de alternativas convencionais de abastecimento, possíveis, em contraste, em núcleos urbanos, vilas e distritos. $\mathrm{O}$ atendimento dessa população é difícil de ser operacionalizado por meio de grandes obras hídricas, como é o caso da transposição do Rio São Francisco. A responsabilidade local (municipal) geralmente é delegada para concessionárias estaduais, que não assumem efetivamente o saneamento rural, resultando na falta de acesso ou em um acesso precário à água, que incide diretamente sobre as famílias mais pobres. 
Parâmetro internacionalmente adotado, proposto por Howard \& Bartram (2003), considera o acesso à água como condição de alcance a uma fonte de água. A depender da distância percorrida e do tempo gasto, além do nível de água coletado pela família e a qualidade da água coletada, definem-se níveis de acesso: sem acesso, acesso básico (20 litros de água pessoa dia obtidos a menos de $1 \mathrm{~km}$ do domicílio), acesso intermediário (50 litros de água por pessoa-dia, fornecidos por torneira pública a menos de 100 metros do domicílio) e acesso ótimo (entre 100 e 200 litros per capita por dia a partir de múltiplas torneiras dentro do domicílio).

As políticas de oferta de água tradicionalmente direcionadas à população rural difusa, como a pequena açudagem e a perfuração de poços (Campos, 2012), foram insuficientes e na prática não viabilizavam o acesso à água em quantidade, qualidade e proximidade adequadas. No que se refere ao acesso à água para consumo humano (beber, cozinhar e uso doméstico), a situação mais comum para essa população, até meados dos anos 2000, era a necessidade de percorrer longas distâncias diárias, a pé ou de carroça, para buscar água de baixa qualidade em açudes e barreiros, que também serviam à dessedentação animal, ou em poços, muitas vezes salinizados, e chafarizes públicos. Segundo os parâmetros internacionais de acesso à água apresentados acima, essas famílias não tinham assegurado sequer um acesso básico à água que lhes garantisse água para as necessidades mais elementares, com alto grau de efeitos nocivos à saúde. No que se refere ao acesso à água para a atividade agropecuária, guardadas as exceções, essa população rural difusa também não dispõe de água para a produção de alimentos, praticando quase que exclusivamente uma agricultura de sequeiro.
Depois do período chuvoso, as fontes de água se reabastecem, mas, com o avançar do período do estio, as fontes próximas vão secando, criando a necessidade de buscar água ainda mais longe. Se a seca é prolongada, a situação ganha feições de calamidade social, acionando-se a solução paliativa da distribuição emergencial de água por carros-pipas. Apenas em meados dos anos 2000 essa situação começa a mudar, com o início da implementação de uma política de construção de cisternas de placas que alcança diretamente essa população de forma abrangente e efetiva quanto à melhoria do acesso à água a partir das possibilidades de seu armazenamento. Veremos a seguir como surge e se desenvolve essa política.

\section{Do P1MC ao Programa Cisternas: a apropriação no Estado da política de construção de cisternas}

A cisterna de placas pré-moldadas é um tipo de reservatório de água cilíndrico, com capacidade de armazenamento variada (sendo as mais comuns empregadas pelo Programa a de 16 mil litros, voltada para o consumo humano, e a de 52 mil litros, voltada para a produção de alimentos). A cisterna de consumo (16 mil litros) é coberta, semienterrada e armazena água das chuvas captada do escoamento dos telhados das casas, com a utilização de calhas de zinco ou PVC. Ela é construída a partir de placas de concreto fabricadas no local de construção, em moldes de madeira. O reservatório é protegido da evaporação e das contaminações causadas por animais e dejetos trazidos pelas enxurradas (Brasil, 2005b). A cisterna de 52 mil litros também é coberta, mas é completamente enterrada e armazena 
água das chuvas captada diretamente do solo, canalizando as enxurradas (cisterna de enxurrada) ou a partir de uma calçada, também construída a partir de placas de concreto (cisterna calçadão).

O processo de construção é participativo ${ }^{6}$, envolvendo famílias e comunidades. A escavação do buraco, por exemplo, onde será erguida a cisterna de consumo é realizada pela mão de obra familiar e tida como contrapartida da família. Agricultores da comunidade são treinados como pedreiros ou cisterneiros e passam a ser os responsáveis pela construção, mas recebem auxílio da família e da comunidade, seja como ajudantes ou com o oferecimento de abrigo e alimentação aos mesmos. A cisterna é uma solução simples, de uma técnica facilmente adaptável à baixa situação educacional do povo do sertão, sendo também de baixo custo (ASA, 2002).

A construção de cisternas de placas para armazenamento de água como ação pública é uma proposta que surge entre o final dos anos 1990 e o início dos anos 2000, por meio da sociedade civil organizada em torno da Articulação Semiárido Brasileiro (ASA), que sistematiza a experiência de várias organizações atuantes no semiárido e elabora o documento-base do Programa de Mobilização e Formação para a Convivência com o Semiárido: Um Milhão de Cisternas Rurais (P1MC), a ser executado pelas próprias organizações da sociedade civil ${ }^{7}$.
O documento (ASA, 2002) sugere uma nova cultura de política de participação, que supõe a ampliação da inserção das comunidades nos processos de construção de políticas públicas, bem como a gestão, a fiscalização e o acompanhamento dessas políticas, superando métodos de consultas tecnocráticas tradicionais, que funcionam como aparências de participação. Nessa perspectiva, os beneficiários também são implementadores (sujeitos) da política pública.

É nesse período também que começa a se delinear o paradigma da Convivência com o Semiárido, a partir do adensamento das críticas às políticas de combate à seca. Pereira (2016) identifica quatro ações públicas que estão na origem da criação da "lógica de convivência com o semiárido": a atuação da Conferência Nacional dos Bispos do Brasil (CNBB) com Projetos Alternativos; a atuação da Embrapa Semiárido na avaliação, no aprimoramento e no desenvolvimento de tecnologias para a convivência com a seca; a Rede Projeto Tecnologias Alternativas (PTA); e a luta dos movimentos sindicais rurais, tendo como marco a ocupação da SUDENE em 1993 (Pereira, 2016).

Essas ações públicas dão origem à e fortalecem a atuação de diversas organizações da sociedade civil (pastorais, dioceses e organizações ligadas às igrejas católica e protestante, sindicatos de trabalhadores rurais, federações sindicais, associações

\footnotetext{
${ }^{6}$ A participação é uma categoria usada pelos próprios formuladores da política e que aparece transversalmente em todo o P1MC. Além da participação na construção das cisternas, o Programa tem como objetivo específico, por exemplo, criar mecanismos que promovam a participação de todos os atores envolvidos na gestão do projeto e no controle social (ASA, 2002, grifo meu). Daí a importância dos componentes do Programa de mobilização social e controle social. Mais tarde, essa dimensão foi incorporada ao conceito de tecnologia social de acesso como "um conjunto de técnicas e de métodos aplicados para a captação, o armazenamento, o uso e a gestão da água, desenvolvidos a partir da interação entre o conhecimento local e técnico, apropriados e implementados com a participação da comunidade" (Brasil, 2018).

${ }^{7} \mathrm{O}$ intuito da proposta foi construir um milhão de cisternas de placas no semiárido em um período de cinco anos, cujo financiamento deveria vir tanto do poder público como da iniciativa privada.
} 
de base comunitária, ONGs - de pesquisa, extensão rural, de apoio à agricultura familiar e/ou à difusão de tecnologias alternativas, cooperativas, movimentos de mulheres, entre outros), sendo a maioria delas fundamentais para a constituição da rede ASA.

A III Conferência das Partes da Convenção de Combate à Desertificação das Nações Unidas (COP 3), ocorrida entre 15 e 26 de novembro de 1999, em Recife (PE), é o marco da constituição da rede ASA. Reunido em um fórum paralelo de discussões, em um contexto de mais uma seca plurianual, um conjunto de organizações da sociedade civil (OSCs) divulga um documento intitulado Declaração do semiárido, indicando que "o semiárido que a Articulação está querendo construir é aquele em que os recursos seriam investidos nos anos 'normais', de maneira constante e planejada, em educação, água, terra, produção, informação [...]" (ASA, 1999).

A constituição da rede ASA e o P1MC representam, assim, o segundo momento de todo um processo de "experimentação social" que vinha ocorrendo no semiárido nos anos 1990, em um contexto de maior espaço para processos participativos na sociedade e a emergência do conceito de desenvolvimento sustentável. Esses experimentos, levados a cabo por "novos" atores políticos e sociais (ONGs, igrejas, movimento sindical, etc.), buscavam construir uma nova prática política na região (Diniz \& Piraux, 2011).

Desde então, esse subconjunto amplo de organizações da sociedade civil do semiárido continuou sistematizando reflexões e propostas endereçadas principalmente à realidade da população rural do semiárido buscando: disseminar a cultura de estoque (água e alimentação humana e animal), disseminar a prática de uma agricultura agroecológica, democratizar o acesso à terra e à água, valorizar o saber local e associá-lo com o saber científico, promover a educação contextualizada, e mobilizar, formar e organizar a população para a busca de direitos (Conti \& Schroeder, 2013).

A eleição de Luiz Inácio Lula da Silva em 2002 abre um novo campo de possibilidades para a elaboração e a implementação de políticas sociais e a ASA irá se beneficiar desse contexto. A partir de 2003, um conjunto de políticas públicas de combate à pobreza rural ganharia densidade com impactos significativos no semiárido, envolvendo saúde, educação, saneamento básico, acesso à água potável, eletrificação rural, transferência de renda condicionada - Bolsa Família - e programas de apoio à agricultura familiar - como o Programa Nacional de Fortalecimento da Agricultura Familiar (PRONAF), que foi fortalecido com mais recursos e novas modalidades, como o PRONAF Semiárido, o Programa Garantia-Safra (seguro criado para repor perdas das safras no semiárido), o Programa de Aquisição de Alimentos (PAA) e o Programa Nacional de Alimentação Escolar (PNAE), além dos programas de desenvolvimento territorial (Territórios da Cidadania, Programa Nacional de Desenvolvimento Sustentável dos Territórios Rurais, Programa Territórios Rurais de Identidade) e do Projeto Dom Hélder Câmara.

No que se refere ao acesso à água, como veremos a seguir, o Programa Cisternas oferece o devido suporte à rede ASA e seus Programas de Formação e Mobilização Social para Convivência com o Semiárido: Um Milhão de Cisternas Rurais e Uma Terra e Duas Águas para um Semiárido Sustentável (P1+2), além de viabilizar a execução de ações de acesso à água para consumo humano e para produção de alimentos por governos estaduais e consórcios de municípios, que as articulam com 
suas próprias ações e políticas de apoio à agricultura familiar.

É importante frisar, no entanto, que o acesso à água e a construção de cisternas não constavam na plataforma programática que elegeu Lula, passando a compor o Programa Fome Zero ${ }^{8}$ só a partir dos trabalhos realizados pela equipe de transição. Desse modo, o início do apoio do Governo Federal ao P1MC durante o governo Lula não foi automático, pelo contrário, foi marcado por alguns embates, a começar pela necessária intervenção de Oded Grajew e Frei Beto, assessores à época da Presidência da República, que levaram o projeto ao conhecimento do Presidente. Depois, foi necessário negociar o Projeto no Ministério Extraordinário de Combate à Fome (MESA). "Não foi fácil. Nós enfrentamos um debate muito forte com o Graziano [ex-Ministro Extraordinário de Segurança Alimentar e Combate à Fome]", relatou um dos entrevistados da ASA envolvido na negociação (Arsky, 2019, p. 63). Apesar dos embates, o ano de 2003 se encerra com saldo positivo para a ASA que, além de firmar o primeiro termo de parceria com o Governo Federal, passa a integrar o Conselho Nacional de Segurança Alimentar e Nutricional (CONSEA), importante órgão de assessoramento vinculado diretamente à Presidência da República. Em outras palavras, a ASA logra arquitetar um encaixe institucional ${ }^{9}$ no Estado na medida em que consegue que o governo assuma uma agenda de construção de cisternas passível de ser defendida também no âmbito do CONSEA.

A partir daí, tem início um processo de apropriação no Estado, entendida no sentido tanto de interpretar como de se apoderar do projeto e das formulações elaboradas pela sociedade civil. Analiticamente, considera-se que esse processo passa por quatro dinâmicas, quais sejam: a apropriação no Estado do P1MC, a apropriação no Estado do P1+2, a incorporação do tema do acesso à água na agenda de segurança alimentar e nutricional (SAN), e a incorporação de estados e municípios na execução do Programa e suas respectivas apropriações locais.

A apropriação do P1MC no Estado ${ }^{10}$ tem início com os desafios internos de manter e viabilizar a parceria em um contexto institucional de pouca prioridade para o tema, merecendo destaque o papel da burocracia responsável pela gestão da parceria no convencimento interno junto aos dirigentes da Secretaria e do Ministério e dos órgãos de assessoramento, como a Consultoria Jurídica (CONJUR) e o Controle Interno do Ministério do Desenvolvimento

\footnotetext{
${ }^{8}$ Embora o semiárido fosse uma região prioritária para o Governo, o acesso à água e a construção de cisternas não constavam no documento base do "Projeto Fome Zero" (Instituto Cidadania, 2001), sendo incorporado ao "Programa Fome Zero" somente a partir de sua execução em 2003. ${ }^{9}$ O conceito de encaixe (fit) foi trazido por Skocpol (1992), que analisou a origem das políticas sociais nos Estados Unidos. Naquele país, argumenta a autora, o desenvolvimento de políticas de proteção às mulheres (e crianças) pode ser explicado pelo encaixe "entre as capacidades organizacionais dos movimentos por mulheres e as oportunidades oferecidas pelas instituições políticas americanas” (Skocpol, 1992, p. 56). A noção de encaixe está associada, portanto, à ideia de permeabilidade ou porosidade do Estado à participação de certos atores sociais.

${ }^{10}$ Aqui cabe esclarecimento: a referência a uma apropriação no Estado se dá em função do envolvimento de órgãos e atores que constituem o aparelho administrativo do Estado, como CGU, TCU, AGU, gestores e servidores públicos, processo que se correlaciona, mas não se limita, à apropriação realizada pelos governos eleitos e seu bloco dirigente. Nota-se que aqui a ênfase recai em um processo de apropriação que vai da sociedade em direção ao Estado, mas há de se sublinhar a apropriação que ocorre na direção inversa, no momento da implementação, na qual um projeto mais ou menos coerente dá lugar a apropriações dispersas, seguidas de momentos de redefinição, ajustamento (negociação de interesses), confrontação e também de aprendizagem para os atores envolvidos (Lascoumes \& Le Gales, 2012, p. 91).
} 
Social e Combate à Fome (MDS). Perguntado como se deu esse processo, o gestor nacional do Programa à época relatou que havia um certo "estranhamento" do corpo diretivo, pois o Ministério "na verdade não tinha se organizado para gerenciar ou para criar um programa". A negociação constante com a ASA também foi bem destacada pelo entrevistado, pois "era o tempo todo discutindo, esticando, puxando: - isso não pode, tem que fazer de outro jeito". E só a partir dos resultados "que foi um pouco distensionando a relação" (Entrevista 2; Arsky 2019, p. 77-79).

A partir do segundo mandato do Governo Lula (2007-2010), entram em cena os órgãos de controle interno e externo, Controladoria Geral da União (CGU) e Tribunal de Contas da União (TCU), respectivamente, que auditam intensamente o Programa. "Foram fiscalizações duras", nas quais "os órgãos de controle não tinham nenhum entendimento ou prática de relação com a sociedade civil" (Entrevista 3; Arsky, 2019), sentenciou o presidente da ASA/AP1MC. Nesse contexto, as dinâmicas de incidência e de defesa exercidas por essa burocracia média se intensificam. Incidência nos processos da sociedade civil na execução do Programa, tendo em vista $o$ atendimento às recomendações dos órgãos de controle, mas, ao mesmo tempo, de defesa junto a esses mesmos órgãos, buscando evitar a distorção dos aspectos centrais do programa e da parceria.

A constituição do Programa Cisternas, conforme apontado anteriormente, será determinada por outras três dinâmicas, a começar pelo início do apoio a outro programa formulado pela ASA, o $\mathrm{P} 1+2$, que, diferentemente do P1MC, "encontrou uma estrada construida de receptividade do governo" (Entrevista 3; Arsky, 2019). A apropriação do $\mathrm{P} 1+2$ pelo Governo ocorre, assim, em um "clima" muito mais cooperativo. Nessas circunstâncias, já se identifica a incorporação pelo Governo do debate realizado pela ASA, que se expressa em torno de um comportamento autônomo da SESAN e do CONSEA em torno do tema do acesso à água e de produção de alimentos para o autoconsumo. " $O$ MDS abraçou o debate interno que a ASA fazia" (Entrevista 27; Arsky, 2019), relatou o coordenador do P1+2 na ASA.

Captando recursos externos e instituindo uma nova ação orçamentária denominada "Acesso à Água para Produção de Alimentos para o Autoconsumo" no Plano Plurianual (2008-2011) do Governo Federal, a SESAN apoia o projeto piloto do $\mathrm{P} 1+2 \mathrm{e}$ apoia a proposta de três governos estaduais: Bahia, Piauí e Rio Grande do Norte. Essa ação passou a ser denominada de $2^{\mathrm{a}}$ água, em complementação à água de consumo humano, que seria a $1^{a}$ água. As duas ações passariam a ser chamadas, genericamente, de "tecnologia social de acesso à água", conceito-chave do posterior Marco Legal do Programa.

O desenvolvimento da ação de $2^{\mathrm{a}}$ água acontece ao mesmo tempo em que as formulações sobre o acesso à água começam a tomar corpo na agenda de segurança alimentar e nutricional, merecendo destaque o papel do CONSEA, principal lócus de debate e formulação da agenda. Refletindo já conhecimento e amadurecimento do tema, o CONSEA, atuando de forma mais ativa, promove entre os dias 4 e 6 de setembro de 2008, em Recife, por ocasião do centenário de Josué de Castro, a primeira reunião plenária exclusiva para tratar do tema da água, nomeada como Acesso e os usos da água no contexto da segurança alimentar e nutricional, ou informalmente conhecida como "Plenária da Água".

Dessa plenária, resultou a Exposição de Motivos n. 011/2008, enviada à Presidência da Re- 
pública, iniciando uma trajetória de contribuições fundamentais do Conselho para considerar o acesso à água de qualidade como um "direito humano básico" que necessita ser efetivado para toda a população. O documento (CONSEA, 2008) aponta quatro dimensões complementares do acesso à água, quais sejam: 1. O abastecimento para uso doméstico de beber e cozinhar, que estaria contemplado pelas cisternas de placas já trabalhadas pela ASA-MDS; 2. A $2^{\mathrm{a}}$ água, que representa a água de produção, alertando para necessidade de alternativas de captação e uso da água para os agricultores familiares que aí vivem e trabalham, voltada à dessedentação de animais e à produção de alimentos; 3 . Água para as comunidades, destacando o papel das "aguadas comunitárias", que servem para suprir os demais usos da casa, da propriedade e da dessedentação de animais; e 4. Água para os vilarejos, para as pequenas cidades e para as cidades maiores, alertando para a multiplicação de atendimento de pequenos vilarejos com canalizações vazias, mas que caracterizam essas comunidades como atendidas.

A incorporação do acesso à água na agenda da SAN fez com que a Gestão Nacional do Programa buscasse formular mais ativamente o tema do acesso à água. Em 2010, SESAN, ASA e CONSEA organizam, com o financiamento da Cooperação Espanhola, um curso de educação a distância denominado "Acesso à água, convivência com o semiárido e segurança alimentar e nutricional". Nesse processo de formulação, algumas constatações foram importantes para a compreensão do lugar que ocupa o acesso à água na perspectiva da SAN: primeira, a captação de água de chuva não é considerada em nenhuma formulação sobre gestão de recursos hídricos (nem na academia, nem nas políticas públicas); segunda, o saneamento rural é preterido no sistema de saneamento que privilegia as áreas mais rentáveis localizadas nas áreas urbanas; terceira, sistemas de abastecimento rural que funcionam são aqueles que preveem gestão comunitária e participativa, como é o caso do Sistema Integrado de Saneamento Rural (SISAR) no Estado do Ceará; quarta, não havia parâmetros de acesso à água na perspectiva da SAN, isto é, que, tendo em vista as características da população rural do semiárido, considerassem a produção alimentar para o autoconsumo (os parâmetros mais consolidados são aqueles do saneamento, que compreendem apenas o uso doméstico, seja no meio urbano ou no rural); quinta, ainda eram incipientes as formulações sobre o direito humano à água (a ONU reconheceu o direito humano à água efetivamente apenas a partir de 2010); sexta, as cisternas de placas e os Sistemas Simplificados de Abastecimento (SSAs) são soluções complementares e para ambas as estratégias era preciso avançar no tema da gestão, caminhando para que, no nível local, se desenvolvesse uma abordagem integrada do acesso à água, que articulasse as diversas alternativas para o suprimento da demanda por água nas comunidades aos seus diversos usos. Para tanto, seria necessário o fortalecimento da participação e do controle social, tanto no Sistema Nacional de Recursos Hídricos (SNRH) como na Política Nacional de Saneamento, além das instâncias de participação previstas no SISAN (Conti \& Schroeder, 2013).

Por fim, mas não menos importante, é preciso destacar o papel das dinâmicas federativas no desenvolvimento e na institucionalização do Programa Cisternas. A força dos entes federados se fez sentir já nos primeiros passos do então criado MDS, a partir de uma diretriz interna de "respeito ao pacto federativo". 
Os convênios celebrados e executados pelos governos estaduais, no período que corresponde ao primeiro mandato do governo Lula (2003-2006), foram marcados pela tentativa desses governos executarem o Programa sem a participação de organizações que compunham a ASA em cada estado, optando assim pela execução direta, via associações comunitárias, modelo do "PCPR" 11 , ou pela contratação de empreiteiras, que apresentaram, no geral, diversos problemas de concepção, além de execução lenta e descontinuada. Com a renovação dos mandatos dos governadores em 2007, alguns governos buscaram rever suas estratégias, apontando para uma maior aproximação e diálogo com a ASA estadual, como no caso dos governos dos Estados da Bahia, Pernambuco e Ceará.

Assim, à guisa de conclusão dessa seção, percebe-se que a apropriação no Estado dos projetos construídos no âmbito da sociedade civil organizada no semiárido, em torno da rede ASA, resulta, reflete e vem acompanhada do desenvolvimento de capacidades estatais para atuar no tema. No sentido do debate contemporâneo de governança, a capacidade estatal ${ }^{12}$ reflete a exis- tência de uma atuação autônoma do Estado, ainda que socialmente inserida ${ }^{13}$. Nesse âmbito, merece destaque o arranjo institucional da política pública que incorporou efetivamente o CONSEA e logrou envolver os entes subnacionais sem abandonar, contudo, a parceria direta do governo federal com a sociedade civil (ASA). Nesse arranjo, revelou-se crucial o papel da Gestão Nacional do Programa Cisternas, constituído pelo que a literatura chama de burocracia de médio escalão ${ }^{14}$. Expressão dessa capacidade estatal foram a criação da Coordenação Geral de Acesso à Água, a realização do I Encontro Nacional dos Parceiros do Programa Cisternas, ainda no último ano do Governo Lula, e o papel que a SESAN teria na formatação, na coordenação e na execução do Programa Água para Todos, no âmbito do Plano Brasil sem Miséria (BSM), já no primeiro Governo Dilma (2011-2014) ${ }^{15}$ (Arsky, 2019). Na próxima seção, trataremos dos efeitos do Programa relacionados à $1^{\mathrm{a}}$ água, trazendo trechos ilustrativos das entrevistas com implementadores locais e microrregionais (BA, PE, AL), que corroboram a percepção também dos implementadores regionais e nacionais entrevistados.

\footnotetext{
${ }^{11}$ PCPR - Programa de Combate à Pobreza Rural, programa de empréstimo do Banco Mundial junto aos governos estaduais do Nordeste, que na sua metodologia prevê a transferência de recursos diretamente às associações comunitárias.

${ }^{12}$ Para a abordagem do tema governança e capacidades estatais no Brasil ver Pires \& Gomide (2016).

${ }^{13}$ Para Evans (1993), trata-se de uma autonomia inserida (embedded authonomy) "em um conjunto concreto de laços sociais que amarra o Estado à sociedade e fornece canais institucionalizados para a contínua negociação e renegociação de metas e políticas” (Evans, 1993, p. 136).

${ }^{14}$ Os burocratas de médio escalão contribuem diretamente para a criação de capacidades estatais: além de serem atores centrais nas capacidades técnico-administrativas do Estado, também podem ter papel relevante na construção de capacidades político-relacionais para a inovação e a governança de políticas públicas (Pires, 2018).

${ }^{15}$ Em 2011, a universalização do acesso à água vira prioridade de governo no âmbito do Plano Brasil sem Miséria, com a instituição do Programa Água para Todos (APT), que promoveria uma ação coordenada por diferentes órgãos de governo. A meta monitorada pelo centro de governo seria a de 750 mil cisternas no semiárido, cabendo ao Programa Cisternas a maior parte da meta: 450 mil cisternas de placas para o consumo humano. Além disso, a SESAN teve papel central na formatação do APT (para o tema, ver Arsky, 2019).
} 


\section{Dignidade, autonomia, disposição de participar e controle social da distribuição de água}

A universalização do acesso à água de beber por meio da construção de cisternas foi alçada à categoria de prioridade no governo Dilma com o Plano Brasil sem Miséria. A meta de 750 mil cisternas chegou a ser superada, mas projeções indicam que a universalização ainda não foi alcançada. Além disso, o orçamento para ação de $2^{\mathrm{a}}$ água e cisternas nas escolas foi consideravelmente ampliado. Posteriormente, o investimento no Programa passou a cair progressivamente a partir de 2015 , até praticamente zerar, sem ter sido alcançada a universalização.

Até junho de 2019, o Programa havia promovido o acesso à água para cerca de 1,3 milhão de famílias: cerca de 1,1 milhão de domicílios do semiárido contam com cisternas de placas de 16 mil litros para armazenar água da chuva para beber e cozinhar alimentos; cerca de oito mil domicílios de outras regiões do país contam com cisternas e outras tecnologias de acesso à água para consumo humano; foram implementadas pouco mais de 200 mil tecnologias familiares e comunitárias de captação e armazenamento de água para o cultivo de alimentos e cuidado com animais; e cerca de 6,8 mil comunidades rurais podem usufruir de cisternas escolares, que ampliam o abastecimento de água durante todo o período escolar (Tabela 1).

Alguns impactos do Programa já são bem conhecidos. Estudos de avaliação mostram que as cisternas proporcionaram, dentre outros benefícios, melhoria da água consumida, diminuição da ocorrência de doenças de veiculação hídrica, melhores condições de saúde, diminuição do tempo e do esforço que a família gasta para buscar água diariamente, principalmente mulheres e crianças (TCU, 2006; EMBRAPA, 2009).

É preciso destacar também impactos indiretos do programa, como: dinamização da economia

TABELA 1 - Tecnologias do Programa Cisternas por UF e região.

\begin{tabular}{|c|c|c|c|c|c|}
\hline Região & $\mathbf{U F}$ & $1^{a}$ água & $2^{a}$ água & Cisternas nas Escolas & Total de Tecnologias \\
\hline \multirow{9}{*}{ Semiárido } & Alagoas & 49.619 & 12.869 & 506 & 62.994 \\
\hline & Bahia & 298.174 & 68.437 & 1408 & 368.019 \\
\hline & Ceará & 251.061 & 31.051 & 991 & 283.103 \\
\hline & Minas Gerais & 65.368 & 13.209 & 426 & 79.003 \\
\hline & Paraíba & 111.063 & 12.770 & 917 & 124.750 \\
\hline & Piauí & 68.026 & 12.043 & 460 & 80.529 \\
\hline & Rio Grande do Norte & 79.367 & 13.738 & 465 & 93.570 \\
\hline & Sergipe & 22.322 & 3.168 & 230 & 25.720 \\
\hline & Subtotal & 1.102 .725 & 203.899 & 6471 & 1.313 .095 \\
\hline
\end{tabular}

FONTE: Relatório de Informações Sociais/Ministério da Cidadania (Brasil, 2019).

Elaboração do autor. Obs.: Financiamento do Orçamento Geral da União e de outras fontes e parceiros do Ministério. 
regional ${ }^{16}$, economia de recursos na aquisição de água por parte das famílias, e qualificação e emprego da mão de obra local, seja dos agricultores familiares das próprias comunidades ${ }^{17}$, seja de técnicos, em grande parte jovens, contratados pelo Programa como animadores e técnicos de campo envolvidos no contato direto com as famílias (Santana et al., 2011).

Segundo parâmetros internacionais, as cisternas de consumo humano teriam garantido às famílias o acesso básico à água, nível mínimo a ser considerado no âmbito dos Objetivos de Desenvolvimento do Milênio (ODM). Nesse nível de acesso, a distância percorrida não ultrapassa um quilômetro, o tempo gasto não ultrapassa 30 minutos e o volume médio coletado é de 20 litros per capita por dia ${ }^{18}$. Nesse caso, o consumo humano e a higiene básica e dos alimentos são garantidos, mas há dificuldade de se garantir a lavagem de roupa e banho. As famílias eventualmente atendidas com algum tipo de sistema de abastecimento simplificado podem alcançar um nível intermediário de acesso ${ }^{19}$ e conseguir fazer o uso doméstico da água encanada (lavar roupa e tomar banho), preservando a água armazenada nas cisternas para consumo humano, porém, são notórios os problemas de fornecimento intermitente e insuficiente de água e casos de distribuição de água não tratada ou salina. Além disso, conforme apontado por Arsky \& Santana (2013), esse referencial adotado pela ONU é incompleto quando aplicado à realidade do semiárido, isso porque não considera o uso produtivo da água. A população rural do semiárido, como visto, é formada basicamente pelo segmento da agricultura familiar e camponesa, que tem no cultivo agrícola e na criação animal suas principais atividades, que asseguram o consumo alimentar e a geração de renda. Considerando que as grandes obras de adução hídrica, quando atendem demandas produtivas, servem aos projetos de irrigação direcionados basicamente aos grandes proprietários, as famílias do semiárido têm nesse ponto um grande gargalo, pois seria "um contrassenso usar a água de abastecimento, com investimento em tratamento, para a produção de alimentos" e "nenhum agricultor teria condições de arcar com o custo", explicou o Prefeito entrevistado de Capela de Alto Alegre-BA (Entrevista 9, Arsky, 2019).

Por carência de água e de sistemas adequados de distribuição, os carros-pipas continuam sendo utilizados, conformando um sistema não convencional de abastecimento de água em muitas áreas do Semiárido (Carvalho, 2012, p. 71). Há de se considerar, no entanto, o papel que a distribuição de água por carro-pipa assume, em um contexto

\footnotetext{
${ }^{16}$ Uma vez que a quase totalidade dos recursos investidos no programa fica na região, na contratação da mão de obra local e, principalmente, no comércio dos municípios, na compra do material para edificação das cisternas e outras aquisições (fornecedores de alimentos, postos de gasolina, entre outros pequenos prestadores de serviços).

${ }^{17}$ Que após passarem por treinamento teórico e prático, tornam-se cisterneiros ou pedreiros, passando não raro a obter renda de outras atividades de construção civil.

${ }^{18}$ Dispostas ao lado do domicílio, as cisternas de 16 mil litros, considerando apenas a captação de água de chuva reservada para o período de estiagem de oito meses, podem dispor: para uma família de quatro pessoas, de 16,6 litros de água por pessoa-dia; para uma família de três pessoas, 22,2 litros de água por pessoa-dia; e para domicílios com apenas duas pessoas, 33,3 litros de água por pessoa-dia.

${ }^{19}$ Quando a água é fornecida por torneira pública a uma distância de $100 \mathrm{~m}$ ou $5 \mathrm{~min}$ para coleta de aproximadamente 50 litros per capita por dia (Howard \& Bartram, 2003).
} 
em que é possível armazenar água em cisternas para a grande maioria da população. Para os operadores da política, o Programa buscava romper definitivamente com os laços de clientelismo e de dependência política das famílias para com soluções ineficientes, alimentadoras da "indústria da seca", e que efetivamente não mudaram a realidade na região (Ruano \& Baptista, 2011). O carro-pipa é, talvez, o símbolo mais conhecido da "indústria da seca". Por esse motivo, muitos operadores do Programa acreditavam, ou desejavam, que a ampliação da cobertura das cisternas acabasse com a realidade do carro-pipa, isso porque a política de benesses e gratidão, característica das iniciativas do combate à seca, ganha contornos dramáticos quando envolve esse elemento essencial à vida, que é a água. Ocorre que, no entanto, mesmo com as cisternas, o carro-pipa continuou sendo uma realidade necessária no semiárido e as pessoas continuam sujeitas à tentativa de uso político, porque a falta de água as coloca em uma situação muito vulnerável, como no caso das grandes secas plurianuais, explica a coordenadora local do MOC na Bahia:

Então, imagina quando seca tudo. E a água da cisterna vai acabando. Como é que não dou um pote de água para meus bodes, minhas galinhas? Ai, o vereador chega lá e diz "não se preocupe, eu vou te dar um pipa”. Se, nesse momento, aquele vereador manda uma água para aquela família, ela vai ficar com um sentimento de gratidão [...]. Então, mas a água é um direito, e o direito não pode ser negociado. (Entrevista 5; Arsky 2019).

Na avaliação dos entrevistados, quando a água chega como um favor, o cidadão fica devendo, fica com gratidão e estabelece-se a relação clientelista, mas, conforme a pesquisa realizada junto a alguns implementadores da política, a cisterna rompe com essa situação generalizada, havendo diminuição do uso político na distribuição de água e mudanças na relação Estado e sociedade civil em âmbito local (Arsky, 2019). Isso ocorreu pelo efeito direto do acesso à água como decorrente da metodologia participativa do Programa. Em primeiro lugar, o acesso básico à água, por meio das cisternas, conferiu dignidade às famílias. "Era grito de socorro porque o povo estava tudo morrendo de sede, e o socorro era o bendito carro-pipa e hoje diminui muito porque foi abrindo o horizonte das pessoas... hoje, com essas cisternas, foi uma mudança de dignidade, deu dignidade" (Entrevista 7, grifo meu; Arsky, 2019), explicou a presidente da Associação de Quixabeira da Matinha, liderança comunitária e beneficiária do programa no município de Feira de Santana (BA). Além disso, conferiu autonomia, porque a família beneficiada "consegue ficar sem depender do carro-pipa. Ela tem independência, tem liberdade, ela não tem que vender o voto por causa do carro-pipa" (Entrevista 13, grifo meu; Arsky, 2019), explicou o presidente da ARCAS (BA).

Foi muito fácil perceber, na observação direta da pesquisa de campo, como se apresentam as categorias dignidade e autonomia. Resultado de um consistente processo de capacitação e conscientização, existe hoje uma verdadeira cultura sobre o gerenciamento da água armazenada na cisterna, e a água de beber armazenada é tratada com zelo e cuidado. Essa reserva adicional, essa poupança, adia ou até mesmo evita as situações limites em que viviam essas famílias.

O acesso à água também, por questão prática, possibilitou que as pessoas se dispusessem a participar do Programa e se envolvessem nos processos de mobilização e formação, isso porque o acesso à 
água "é o inicial, mas é o principal", porque é isso que permite impulsionar as famílias a participarem de outras atividades: "porque, provavelmente, sem água a mulher não participa da reunião e o homem não vem para atividade porque tem que buscar água distante [...] se eu tenho água eu tenho mais tempo disponivel", complementou o presidente da ARCAS (Entrevista 13; Arsky, 2019). Em segundo lugar, há uma questão subjetiva, de dignidade e autoestima necessárias para que haja disposição de participar, "sem isso a família não consegue se engajar em nenhum processo" e é porque "ela foi beneficiada e que as politicas chegaram e que o Estado esteve ali presente, é que ela acredita agora que as coisas vão acontecer" (Entrevista 13; Arsky, 2019). Uma vez envolvidas no Programa, entram em cena os efeitos que decorrem da sua metodologia participativa, que fizeram com que muitos conseguissem compreender a importância da associação comunitária. Nesse sentido, o Programa Cisternas e, particularmente, o P1MC, foi para muitas comunidades um disparador de um processo de participação, organização e engajamento em outras políticas:

A cisterna permite que você experimente uma lógica que está muito além disso: os componentes que vêm com a cisterna, da capacitação, do hábito de reunir a comunidade, de se criar uma comissão, você coloca a associação comunitária nesse processo e a associação é composta por famílias do mesmo perfil de quem vai ser beneficiado. Ela [a família] acredita que depois de ter contribuido com o processo da cisterna, ela acredita que pode contribuir mais, fazer parte de outro conselho municipal e contribuir para que os gestores municipais possam melhorar sua atuação, se colocando para monitorar e até fiscalizar as próximas políticas [...]. É frequente você encontrar uma comunidade onde a maioria é analfabeta, e em muitas comunidades era a primeira vez que a comunidade se reunia para falar dos problemas da comunidade. (Entrevista 13; Arsky, 2019).

Nesse sentido, a proliferação das cisternas, associada ao imprescindível aumento do uso dos carros-pipas devido ao agravamento das secas no semiárido, teria feito a ASA retrabalhar a "questão" do carro-pipa: "Carro-pipa não é nosso inimigo. A gente precisava vencer isso dentro da gente. Porque carro-pipa está na vida da dona Maria, mas também não era nosso aliado porque precisava sobretudo de um controle", então começa "uma caminhada" para despertar nas famílias o controle da qualidade da água: "não, essa água não me serve" (Entrevista 5; Arsky, 2019), relatou a coordenadora do P1MC no MOC (BA). Foi uma mudança natural, assegura outro entrevistado em Alagoas, "pois no início se idealizava um reservatório para armazenar água de chuva, porque antes chovia com mais regularidade". Então, a cisterna começou a "quebrar a cultura do pipa", mas o pipa voltou a crescer com o agravamento da seca, "porém as pessoas começam a melhorar um pouco de vida e quando o poder público começa a querer levar água, você tem onde armazenar água e isso faz toda a diferença". (Entrevista 17, grifo meu; Arsky, 2019), explica o então secretário de Recursos Hídricos do Estado de Alagoas.

A principal crítica ao uso político dos carros-pipas é endereçada às prefeituras, que empregava boa parte do orçamento na distribuição de água por carro-pipa. Nesse âmbito, comum era também que os carros-pipas estivessem a cargo dos vereadores, "a maioria dos carros-pipas era dos vereadores", porém houve mudanças (e ou intensificação) das ações dos governos estaduais e federal, explicou o prefeito entrevistado: 
Hoje, nós temos no município um carro-pipa, que foi dado pelo PAC [Programa de Aceleração do Crescimento]. Temos um convênio com a defesa civil do governo do estado que atende com mais três carros-pipas. E tem o exército. Então, isso não é mais visto como troca de favor. É uma política pública que vem dos três entes federados. Perde-se o espaço para a troca de favor e da institucionalização da indústria da seca (Entrevista 9; Arsky, 2019).

Em Pernambuco, por exemplo, aponta a presidente da Caritas Diocesana do município de Pesqueira, "eles até informatizaram e teve uma experiência que o governo do estado teve que discutir com os próprios conselhos, que diziam as rotas, etc... claro, você tem uso de figuras, mas tem diminuído consideravelmente" (Entrevista 19; Arsky, 2019). Na Bahia, aponta a coordenadora do MOC, "tem municípios em que as organizações dizem não é desse jeito, vamos fazer uma rota, vamos discutir qual a necessidade" e "os conselhos definem as ações da zona rural, inclusive abastecimento por carro-pipa e eles levam água de qualidade" (Entrevista 5; Arsky, 2019).

Então, nesse sentido, o Programa Cisternas teria contribuído para reconfigurar a função e o papel do carro-pipa. Com dignidade e autonomia, as pessoas teriam mudado de comportamento: "então, mesmo quando acontece de o vereador mandar água, a gente vê os relatos de libertação que manda dizer só "muito obrigado"' (Entrevista 5; Arsky, 2019). Além disso, o processo formativo despertou as famílias para a importância da organização comunitária e houve maior controle social da distribuição de água por carro-pipa, um efeito inicialmente não previsto.

Além das bases para potencializar o controle social da distribuição de água por carros-pipas, há a percepção de que melhorou a qualificação da participação da sociedade civil nos conselhos municipais:

Eu acho que a participação dos conselhos municipais das organizações da sociedade civil é um diferencial. Essa relação sociedade civil-poder público, em muitos lugares, a gente conseguiu ter avanços interessantes. A sociedade civil local conseguiu perceber como se dialoga e como traz o próprio poder público local para essa construção. Nós temos vários municípios que isso é uma referência de diálogo, de parceria de construção. Nesse aspecto, nós conseguimos avançar bem. Porque antes não era comum. Chegava a obra na prefeitura e ela fazia do jeito dela, da forma dela. A partir do momento que chegam as cisternas no municipio, um dos critérios para chegar é a participação da sociedade civil, seja nas comissões, seja nos conselhos. E nos conselhos municipais você tem a participação dos diversos atores locais, o que possibilitou um diálogo muito interessante. (Entrevista 19; Arsky, 2019).

Assim, resultado da disposição das pessoas em participar, em se organizar, isto é, em se engajar em processos de ação coletiva, percebe-se também um fortalecimento da sociedade civil em instâncias locais de controle social. Na próxima seção, trataremos dos efeitos do Programa relacionados à $2^{\mathrm{a}}$ água, trazendo trechos de entrevistas que ilustram a percepção dos implementadores entrevistados.

\section{Gerenciamento, diversificação, experimentação e formação útil para outras políticas}

Como sabemos, sem contar com fontes seguras e perenes de água, as famílias lançam mão de uma estratégia variada para obter água para seus 
diversos usos ${ }^{20}$. Fontes distantes, fora da propriedade, pouca serventia tinham para os agricultores no cultivo de hortaliças e outras culturas. Por outro lado, com um reservatório para armazenar água para produção no quintal de casa (ou próximo à casa) é possível garantir a regularidade de água necessária para o cultivo e a criação de pequenos animais. " $A$ água da chuva captada já fornece uma autonomia minima", relatou a agricultora entrevistada em Buique-PE (Entrevista 28; Arsky, 2019), mas as famílias também têm buscado alternativas, como buscar ou bombear água de outras fontes ou comprar água de carro-pipa. O importante é que, uma vez armazenada, permite-se a irrigação diária de hortas, canteiros, fruteiras e outros, dispensando o agricultor da busca diária por água. Na verdade, por essa dificuldade de armazenamento, a maioria das famílias sequer tinha hábito do cultivo e consumo de hortaliças e outras leguminosas.

Nesse sentido, a possibilidade de estocar água para produção reconfigura a estratégia das famílias no gerenciamento das demais fontes existentes (poços e sistemas públicos intermitentes, aguadas, barreiros, tanques, açudes, etc.), como podemos perceber na fala dessa agricultora entrevistada no município de Fátima (BA):

A gente tinha dificuldade com a água, porque daqui da onde a gente mora, para as roças, para os tanques, é bastante longe, e agora não, porque a gente já ganhou a cisterna com bomba, e a extensão já vem com o próprio projeto. [...] Foi bom depois dessa água. Até agora mesmo, os tanques de barro estão secos e os animais estão se abastecendo da cisterna. A gente até parou de plantar um pouco, porque estamos poupando para os animais. [...] Se não fosse ela [a água estocada na cisterna] não dava. Porque a água da EMBASA [Empresa Baiana de Águas e Saneamento] não dá, porque passa da taxa. E, também, nós nem teríamos como armazenar, porque a água vem de oito em oito dias, e nós aqui em cima somos o último a receber, então quando chega nossa vez, já é hora de acabar de novo [...]. A água que tá na cisterna é da chuva e ainda tem como segurar alguns meses. (Entrevista 15; Arsky, 2019).

Em segundo lugar, é preciso sublinhar os efeitos decorrentes do processo formativo realizado junto aos agricultores. Com água e conhecimento, os agricultores tornam-se "agricultores experimentadores", explorando uma diversidade de técnicas e cultivos, o que nos leva a outro efeito percebido, qual seja, a diversificação da produção. O relato abaixo é extenso, mas exemplificativo:

A gente costuma plantar de tudo. É caju, é manga, uva, banana, a gente arrisca uns pezinhos de uva, abacaxi, carambola, tangerina, laranja, mamão, coco, já tem pé de pera. Aqui, a gente diversificou mesmo. É uma diversidade! Ai, o povo diz: "isso não dá". Óxente, porque na minha terra dá? No meu quintal dá. É uma questão de você querer ou não. Quando a gente tá com hortaliça, é uma coisa que não é conhecida mesmo, é o brócolis, a couve-flor. $E$ dá muito porque a gente já tirou muito e cada uma cabeça que o povo se admirava. O que é isso? Eu dizia é couve-flor, é couve-flor e o povo não tinha conhecimento... E era tudo, era berinjela, era pepino, era alface... O que eu pudesse plantar de diferente eu plantava, repolho verde, repolho roxo, aquele coração de boi, tomate, é assim, a gente misturava tudo, eu

\footnotetext{
${ }^{20}$ As tecnologias sociais apoiadas pelo Programa estão justamente alinhadas com os usos necessários das famílias. Por exemplo: a cisterna serve para beber e cozinhar alimentos, o tanque de pedra para lavar roupa e outros usos, a bomba d'água popular para água de emergência e para os animais.
} 
sempre vou arriscando para ver o tomate que dava melhor, o repolho que se dava melhor, para a gente fazer uma continuação do que a gente vê que era mais apropriado aqui [...] ai a gente mistura tudo, vai plantando de tudo um pouquinho [...] agrotóxico, aqui, nunca entrou. Aqui, o pessoal costumava dizer que tomate não dá orgânico e, aqui, a gente tirou tanto tomate, tanto tomate, que não dava conta, e eram poucos pés, mas era tão carregado que era um cacho de tomate e não uma penca. E nunca foi colocado veneno. (Entrevista 15; Arsky, 2019).

Seguindo a metodologia do Programa Cisternas, em particular do $\mathrm{P} 1+2$, com o tempo esses mesmos agricultores geram conhecimento alimentando um circuito de trocas horizontais, de agricultor para agricultor, pondo os mesmos em contato com técnicas, tecnologias, práticas e experiências de manejo e uso da água, agricultura agroecológica e convivência com o semiárido. Desperta-se no agricultor o interesse em "inovar", em experimentar: "Se ele faz, eu também posso fazer" (Entrevista 3; Arsky, 2019), explica o presidente da ASA. Esse diferencial da metodologia transpareceu na entrevista coletiva (roda de conversa) com técnicos que atuam na implementação do Programa Cisternas e de programas correlatos sob a responsabilidade da Associação Regional de Agricultura Apropriada (ARCAS):

Se a família não vê a outra, ela não faz, ela não acredita, ela não tem norte, não tem horizonte... O Globo Rural não ensina, não, não é assim. Eu estou falando de você colocar o povo em um ônibus, pousar uma noite em uma pousada, passar o dia em uma propriedade aprendendo, vendo. [...] Você via a diferença das conversas na ida e da volta, no ônibus com os agricultores. Na volta, os agricultores vêm falando de tudo. "Você viu seu Zé, com duas tarefinhas, com a cisterna o tanto que ele produz", "ah eu vou fazer", "ah, eu vou fazer também” - é fantástico. Estamos pensando fazer intercâmbio no programa de ATER [Assistência Técnica e Extensão Rural] também. (Entrevista 12; Arsky, 2019).

O conhecimento técnico e acadêmico também é empregado, mas é traduzido, adaptado e trabalhado a partir da realidade local. As famílias passam por cursos teóricos e práticos, com destaque para o curso de Sistemas Simplificados de Manejo da Água (SISMA) e Gestão da Água para Produção de Alimentos (GAPA). Tal processo formativo, de acordo com a pesquisa e os entrevistados já citados, serviu como uma espécie de etapa preparatória para a entrada de outras políticas voltadas à agricultura familiar:

[...] A gente sente a diferença de conversar com as famillias que têm $2^{a}$ água e as que não têm, porque elas já passaram pelas capacitações do SISMA, do GAPA... Essas estão com a mente mais aberta para receber as informações do técnico. [...] Quando você pega uma família que já tem cisterna, já passou pelo GAPA, SISMA e você chega com fomento e assistência técnica é outra resposta. Você vê a família em um processo de desenvolvimento. É muito satisfatório. (Entrevista 12; Arsky, 2019).

Se no começo o foco da $2^{a}$ água era segurança alimentar, agora entra a questão do crédito, da cadeia produtiva e do emprego e renda. Eles não tinham dimensão disso. O acesso à água foi a porta de entrada. (Entrevista 17 - AL; Arsky, 2019).

Não por acaso as ações de $2^{\mathrm{a}}$ água se tornaram eixos estruturantes das iniciativas de apoio à agricultura familiar e de combate à pobreza rural no semiárido, conforme relato de gestores nos três níveis de governo (Arsky, 2019). No plano nacional, 
relatou o então presidente da ASA, uma importante convergência de Programas começou a se desenhar. No Governo do Estado de Pernambuco, por exemplo, o Programa, dada sua abrangência, articulava-se e apoiava outras ações. No plano municipal, teria contribuído com o papel das secretarias de Agricultura:

Cisterna de produção e fomento [Programa de Fomento às Atividades Produtivas Rurais] ... Tá rolando, já estamos pagando fomento... É novo... Foi um diálogo muito interessante e tá sendo muito bom... Uma experiência que pode levar a um outro tipo de política. (Nível federal - Entrevista 3, Arsky, 2019).

O Programa Cisternas é o carro-chefe da Secretaria da Agricultura Familiar [...] O programa do leite e o programa do PAA só foi possivel ampliar porque tinha um mote de como chegar nas comunidades. (Nível estadual -PE Entrevista 23; Arsky, 2019).

Ave Maria, se você ouvir a fala dos secretários de agricultura, todos vão dizer a mesma coisa: que o consórcio potencializou as ações da secretaria, principalmente essas ações da $2^{a}$ água. Depois da tecnologia, ela faz o acompanhamento e direciona a assistência técnica, que é justamente a expertise $d a$ secretaria porque você imagina incentivar alguém que não tem água, é mais difícil. (Nível municipal Entrevista 8, Arsky, 2019).

Assim, do ponto de vista das famílias de agricultores do semiárido, a ampliação do acesso à água segue sendo elemento central, que possibilita que a família amplie e diversifique a produção. Não há ainda avaliações quantitativas do impacto desse atendimento, mas o que se sabe é que existem milhares de experiências que deram certo. Já do ponto de vista das políticas públicas percebe-se que, em um contexto de adensamento de políticas públicas para a população da região durante o Plano Brasil sem Miséria, as ações de acesso à água tornam-se centrais nas estratégias dos formuladores e implementadores.

\section{Considerações finais}

O processo histórico de formação econômica e social do semiárido resultou em uma distribuição extremamente desigual da terra (e consequentemente do acesso às fontes de água) e na existência de uma frágil, porém numerosa, classe de pequenos agricultores familiares (camponeses). A intervenção pública, sempre alavancada politicamente na época das secas, ancorada no paradigma do combate à seca, não alcançou de forma efetiva essa população, sendo caracterizada por uma intervenção assistencialista, paternalista e clientelista. Tampouco se observou, de forma articulada e contínua, programas de melhoria da distribuição de água para as populações rurais, de forma que persistia no semiárido uma situação generalizada de insegurança hídrica, principalmente para a população rural difusa.

A atuação de um amplo conjunto de organizações da sociedade civil no semiárido fez surgir e se desenvolver um novo paradigma de política pública para a região, ancorado na lógica da convivência com o semiárido em contraposição à lógica do combate à seca. Atuando em rede, a principal iniciativa da ASA foi a proposição do Programa de Formação e Mobilização Social para Convivência com o Semiárido: Um Milhão de Cisternas Rurais, que refletia uma percepção extremamente aguçada da premente necessidade desta população por acesso à água de qualidade. 
Neste artigo, nós percorremos a trajetória de apropriação no Estado dessa formulação de política concebida no âmbito da sociedade civil organizada, que ganha forma no Programa Nacional de Apoio à Captação de Água de Chuva e Outras Tecnologias Sociais de Acesso à Água - Programa Cisternas (Lei 12.87/2013). Vimos que essa trajetória veio acompanhada do desenvolvimento de capacidades estatais para sustentar um arranjo institucional capaz de lograr alcançar uma meta tão ambiciosa de cobertura. Além do papel da Gestão Nacional do Programa Cisternas, constituído pelo que a literatura chama de "burocracia de médio escalão", que dá sustentação à atuação da Secretaria Nacional de Segurança Alimentar e Nutricional, mereceram destaque o envolvimento efetivo do CONSEA e a participação dos demais entes subnacionais que foram incorporados de forma complementar à parceria direta do governo federal com a sociedade civil (ASA).

Chegando em mais de um milhão de famílias dispersas na imensidão da zona rural do semiárido, em níveis bem próximos da universalização do atendimento, é seguro afirmar que o Programa Cisternas reconfigurou o acesso à água na zona rural do semiárido. Essa reconfiguração, conforme a percepção dos entrevistados, é resultado tanto dos efeitos práticos da própria existência de um ou mais reservatórios de água à disposição das famílias como de um efeito subjetivo decorrente da metodologia participativa do programa. $\mathrm{O}$ acesso à água trouxe dignidade e autonomia às famílias. Além de mudar sua percepção sobre a distribuição de água pelos carros-pipa, progressivamente percebida como um direito e não um favor, despertou-lhes para a importância da participação e da organização comunitária. Essa disposição a participar pôde ser sentida em uma maior qualificação da representação da sociedade civil nos conselhos municipais, inclusive no que se refere ao controle social da distribuição da água por meio dos carros-pipas. As cisternas e os carros-pipas são, hoje, dois elementos de uma espécie de sistema de abastecimento não convencional.

É comum na literatura especializada a formulação de críticas direcionadas ao Programa e às cisternas usando como parâmetro aquilo que tal política pública não se propôs a fazer sozinha, como superar a pobreza ou a injustiça hídrica, minimizando os efeitos do Programa ao explorar aspectos estruturais de continuidade da realidade do Semiárido. O que esse artigo busca evidenciar, por outro lado, é que grandes avanços no acesso à água foram alcançados, apesar dos aspectos estruturais de continuidade. Nesse sentido, categorias utilizadas aqui, como dignidade e autonomia, que ganham força explicativa pela convergência dos relatos de atores diferentemente posicionados no processo de implementação, não devem ser tomadas como valores absolutos, mas como importantes avanços em relação a uma situação imediatamente anterior extremamente desfavorável.

Do mesmo modo, com relação às famílias que receberam ações de $2^{\mathrm{a}}$ água, foram destacados efeitos decorrentes dessas duas dimensões: efeitos decorrentes do acesso à água propriamente dita $\mathrm{e}$ efeitos decorrentes da metodologia de implementação do Programa. A possibilidade de estocar água para produção reconfigura a estratégia das famílias no gerenciamento das demais fontes existentes. Aliado aos efeitos decorrentes do processo formativo do Programa, formou-se um conjunto grande de "agricultores experimentadores" que alimentavam um circuito horizontal, de agricultor para 
agricultor, de troca de experiência e conhecimento. Assim, as tecnologias sociais de acesso à água para a produção de alimentos se mostraram essenciais para a ampliação e a diversificação da produção das famílias agricultoras beneficiadas, seja pela própria possibilidade de estocar água de chuva, seja pelo efeito de permitir um melhor gerenciamento das demais fontes de água, ou pelo conhecimento e pela disposição causados pelo processo formativo do Programa. Devido à importância do acesso à água na vida das famílias, e em um contexto de adensamento das políticas de apoio à agricultura familiar e combate à pobreza rural, as ações de $2^{\mathrm{a}}$ água ganharam centralidade nas estratégias dos três entes federados.

A reversão da ampliação da cobertura do Programa a partir de 2015, bem como a interrupção do programa no momento atual e do desmonte de outras políticas associadas, revelam, em verdade, um potencial não realizado de transformação, que

\section{Referências}

Albuquerque Jr., D. M. de. A invenção do Nordeste e outras artes. 5. ed. São Paulo: Cortez, 2011.

Andrade, M. C. Nordeste: alternativas da agricultura. Campinas: Papirus, 1988.

Arsky, I. C. Determinantes, efeitos e a institucionalização do Programa Cisternas na visão dos implementadores. Rio de Janeiro, Dissertação (Mestrado em Ciências Sociais em Desenvolvimento, Agricultura e Sociedade) - CPDA/ UFRRJ, 2019.

Arsky, I. C.; Santana, V. L. Parâmetros de demanda hídrica no Semiárido. In: Conti, I. L.; Schroeder, E. O. (Org.). Convivência com o semiárido brasileiro: autonomia e protagonismo social. Brasília: AECID/MDS/Editora IABS/ FAURGS/REDEgenteSAN, 2013. se vislumbrava a partir da ruptura histórica que fez emergir conceitos, práticas e políticas relacionados à convivência com o semiárido e às tecnologias sociais de acesso à água.

Nesse sentido, o Programa Cisternas mudou o acesso à água no semiárido, mas o acesso à água continua sendo eixo central de toda e qualquer estratégia de transformação da realidade dessa população, seja a ampliação do acesso à água de uso doméstico, com a universalização das cisternas, a gestão comunitária de sistemas simplificados, o controle social do carro-pipa e a "luta pela água", democratizando o acesso a adutoras e canais construídos nos últimos anos, seja o acesso à água para a produção de alimentos, com a necessária ampliação de atendimentos da $2^{\mathrm{a}}$ água, associados ao aprimoramento e à difusão de técnicas de manejo, uso e conservação da água para finalidades produtivas, e ao assessoramento técnico para a produção alimentar agroecológica.

ASA - Articulação Semiárido Brasileiro. Declaração do Semiárido: propostas da articulação no semiárido brasileiro para a convivência com o semiárido e combate à desertificação. Recife: ASA, 1999.

ASA - Articulação Semiárido Brasileiro. Programa de Formação e Mobilização Social para a Convivência com o Semiárido: Um Milhão de Cisternas Rurais - P1MC. Recife: ASA, 2002.

Brasil. Ministério da Integração Nacional. Nova delimitação do semiárido brasileiro. Brasília, 2005a. Disponível em: $<$ https://www.mdr.gov.br/images/stories/ArquivosSNPU/ Biblioteca/publicacoes/cartilha_delimitacao_semi_arido. pdf $>$ 
Brasil. Ministério do Desenvolvimento Social e Combate à Fome. Relatório de Gestão. 2004. Unidade Jurisdicionada: Secretaria Nacional de Segurança Alimentar e Nutricional. Brasília, 2005b.

Brasil. Ministério do Desenvolvimento Social e Combate à Fome. Relatório de Gestão. 2007. Unidade Jurisdicionada: Secretaria Nacional de Segurança Alimentar e Nutricional. Brasília, 2008.

Brasil. Casa Civil. Decreto no 9.606, de 10 de dezembro de 2018. Brasília, 2018. Disponível em: <http://www.planalto. gov.br/ccivil_03/_Ato2015-2018/2018/Decreto/D9606. htm\#art22>. Acesso em 03 dez. 2020.

Brasil. Ministério da Integração Nacional. Nova delimitação do semiárido. Brasília, 2017. Disponível em: $<$ http://www. sudene.gov.br/delimitacao-do-semiarido $>$. Acesso em: 11 jul. 2019.

Brasil. Ministério da Cidadania/Secretaria de Avaliação e Gestão da Informação (SAGI). Relatório de Informações Sociais - RI de Segurança Alimentar e Nutricional. Brasília, 2019. Data de referência: junho de 2009. Disponível em: $<$ https://aplicacoes.mds.gov.br/sagi/RIv3/geral/index.php>. Acesso em: jul. 2009.

Brasil; GTDN - Grupo de Trabalho para o Desenvolvimento do Nordeste. Uma política de desenvolvimento econômico para o nordeste. Rio de Janeiro: Imprensa Nacional, 1959. Disponível em: <https://web.bndes.gov.br/bib/jspui/handle/1408/17760>.

Buainain A. M.; Garcia J. R. Capítulo V: Pobreza rural e desenvolvimento do Semiárido Nordestino: resistência, reprodução e transformação. In: Buainain A. M.; Dedecca C. (Org.). A nova cara da pobreza rural: desenvolvimento e a questão regional. V. 17. Brasília: IICA, 2013. (Série Desenvolvimento Rural Sustentável)

Bursztyn, M. O poder dos donos: planejamento e clientelismo no Nordeste. Fortaleza: BNB, 2008.

Campos, J. N. B. A evolução das políticas públicas no Nordeste. In: Agência Nacional de Águas; Centro de Gestão e Estudos Estratégicos. A questão da água no Nordeste. Brasília: CGEE, 2012.
Carvalho, O. As secas e seus impactos. In: Agência Nacional de Águas; Centro de Gestão e Estudos Estratégicos. $A$ questão da água no Nordeste. Brasília: CGEE, 2012.

CONSEA - Conselho Nacional de Segurança Alimentar e Nutricional. $O$ acesso e os usos da água no contexto da soberania e da segurança alimentar e nutricional. Plenária do CONSEA, Brasília, 5 set. 2008.

Conti, I. L.; Schroeder, E. O. (Org.). Convivência com o semiárido brasileiro: autonomia e protagonismo social. Brasília: AECID/MDS/Editora IABS/FAURGS/REDEgenteSAN, 2013.

Diniz P. C. O.; Piraux, M. Das intervenções de combate à seca às ações de convivência com o semiárido: trajetória de "experimentalismo institucional' no semiárido brasileiro. Cadernos de Estudos Sociais, Recife, 26(2), 2011.

EMBRAPA - Empresa Brasileira de Pesquisa Agropecuária. Avaliação da sustentabilidade do Programa Cisternas do MDS em parceria com a ASA. Petrolina: FUNDER/FAOEmbrapa Semiárido-SAGI/DAM/MDS, 2009.

Evans, P. O Estado como problema e solução. Lua Nova: Revista de Cultura e Política, 28-29, 107-157, 1993. doi: 10.1590/S0102-64451993000100006

Furtado, C. A fantasia desfeita. 3. ed. São Paulo: Paz e Terra, 1989.

Howard, G.; Bartram, J. Domestic water quantity, service and health. Geneva: World Health Organization, 2003.

INSA - Instituto Nacional do Semiárido (INSA). Sinopse do censo demográfico para o semiárido brasileiro. Campina Grande: INSA, 2012.

IPEA - Instituto de Pesquisa Econômica Aplicada. Políticas Sociais: acompanhamento e análise, $\mathrm{n}^{\circ} 21$. Capítulo 7 - Desenvolvimento Rural, 2013.

Instituto Cidadania. Projeto Fome Zero - Documento Síntese: uma proposta de política de segurança alimentar para o Brasil. São Paulo: Instituto Cidadania, 2001.

Lascoumes, P.; Le Gales, P. Sociologia da ação pública. Maceió: Edufal, 2012. 
Nobre, P. A origem das águas no Nordeste. In: Agência Nacional de Águas; Centro de Gestão e Estudos Estratégicos. A questão da água no Nordeste. Brasília: CGEE, 2012.

Pereira, M. C. G. Água e convivência com o semiárido: múltiplas águas, distribuições e realidades. São Paulo, Tese (Doutorado em Administração Pública) - CDAPG, Escola de Administração de Empresas de São Paulo, 2016.

Pires, R. O trabalho na burocracia de médio escalão e sua influência nas políticas públicas. In: Pires, R.; Lotta, G.; Oliveira, V. E. (Org.). Burocracia e políticas públicas no Brasil: intersecções analíticas. Brasília: IPEA, 2018.

Pires, R.; Gomide. A. Governança e capacidades estatais: uma análise comparativa de programas federais. Rev. Sociol. Polit., 24(58), jun. 2016.

Ruano, O.; Baptista, N. Acesso à água como fator de Segurança Alimentar e Nutricional no Semiárido Brasileiro. Fome Zero: uma história brasileira. V. 1. Brasília, 2011.

Santana, V. L.; Arsky, I. C.; Soares, C. C. S. Democratização do acesso à água e desenvolvimento local: a experiência do Programa Cisternas no semiárido brasileiro. In: Anais do
I Circuito de Debates Acadêmicos, CODE, 2011. Brasília: IPEA, 2011.

Silva, R. M. A. Entre o combate à seca e a convivência com o Semiárido: transições paradigmáticas e sustentabilidade do desenvolvimento. Brasília, Tese (Doutorado em Desenvolvimento Sustentável) - CDS/UNB, 2006.

Skocpol, T. Protecting Soldiers and Mothers: The Political Origins of Social Policy. Cambridge: The Belknap Press of Harvard University Press, 1992.

Souza Filho, F. A. A água do futuro e o futuro das águas. In: Agência Nacional de Águas; Centro de Gestão e Estudos Estratégicos. A questão da água no Nordeste. Brasília: CGEE, 2012.

Suassuna, J. Potencialidades hídricas do nordeste brasileiro. Parcerias Estratégicas, 20, 2005. Disponível em: http:// www.cgee.org.br/arquivos/p_20_1.pdf

TCU - Tribunal de Contas da União. Relatório de avaliação de programa: Ação Construção de Cisternas para Armazenamento de Água. Relator: Ministro Guilherme Palmeira. Brasília: TCU, Secretaria de Fiscalização e Avaliação de Programas de Governo, 2006. 